\title{
Government Employee Disclosures of Agency Wrongdoing: Protecting the Right to Blow the Whistle
}

Questionable conduct by a government agency or officer almost inevitably comes to the attention of lower echelon employees. Staff personnel, denied the institutional power to decide what information should be released to the public, may neverthless decide to disclose evidence of the alleged misconduct. Disclosure may be intended merely to embarrass a disliked superior or coworker or to further the disclosing employee's own interests. In other cases the employee may be spurred by his conception of the interests of the agency, the government, or the public. As employee, taxpayer, or citizen, he may feel compelled to reveal conduct that he believes is detrimental to those interests.

But whether the motivation is selfish or selfless, the civil servant who discloses misconduct subjects himself to a variety of possible sanctions by his employer agency, ranging from dismissal, suspension and official reprimand to more subtle measures such as denial of promotions or benefits. These reprisals may themselves be motivated by vengefulness or self-interest, but they may serve important and legitimate interests by helping to preserve necessary secrecy, intra-agency harmony, or employee competence. ${ }^{1}$ Ultimately, then, in any attempt to define the scope of the rights of government employees to disclose facts uncovered in the course of their employment, opposing aspects of the public interest must be considered. ${ }^{2}$ Dissident employees, however motivated, can perform a critical function by bringing improper agency policies or actions to light. On the other hand, allowing unrestricted disclosure would deny government agencies the modicum of confidentiality that is essential for their efficient operation and might also prevent them from removing employees whose disclosures cause unwarranted harm or demonstrate lack of fitness for their positions.

This comment examines the disclosure rights of federal and state government employees whose job duties confer neither special privilege nor limitation with respect to employment related disclo-

' See note 15 infra.

${ }^{2}$ See generally Whistue Blowing (R. Nader, P. Petkas \& K. Blackwell eds.) 1972. 
sures. ${ }^{3}$ It first identifies each of the various substantive grounds, both constitutional and statutory, for a right of employee disclosure. The comment attempts to provide a relatively comprehensive survey of the protection available to a disclosing employee by discussing the overlapping applications of the separate substantive grounds as they have been interpreted by the courts. The final section of the comment surveys and discusses the procedural protections that must be adhered to when the government seeks to sanction an employee for making a disclosure that has harmed his agency's interests. In both substantive and procedural areas, the courts have reached an uneasy balance between the public interest in favor of and in opposition to the expansive protection of government employee disclosures.

\section{Substantive Rights of the Public Employee}

The right of government employees to make certain workrelated disclosures without being sanctioned by their agency employers arises from two distinct sources. The first includes the constitutional guarantees of freedom of speech and petition. The second source is the body of federal and state statutes that bar dismissal of employees except where cause for removal has been established. The focus of the constititutional right is protection for the employee's speech activities, while the focus of the statutory right has become the vindication of the government's interests in restricting other conduct of its employees. The two sources thus present different aspects of the same fundamental problem-that of providing workable criteria for determining which disclosures are protected and which are not.

\section{A. Constitutional Protections}

1. First Amendment Freedom of Speech: Pickering and Its Progeny. Public employees long suffered under a status of "constitutional orphanage" that allowed their employers to dismiss them almost at will. The traditional rationale for incomplete public

${ }^{3}$ Policymakers serving at the discretion of their superiors are thus excluded from discussion. Likewise, the issues of national security and the government's power to compel secrecy by statute are noted only in passing; for an extensive treatment of that subject, see Edgar \& Schmidt, The Espionage Statutes and Publication of Defense Information, 73 Colum. L. REv. 929 (1973).

- See Van Alstyne, The Constitutional Rights of Public Employees: A Comment on the Inappropriate Uses of an Old Analogy, 16 U.C.L.A.L. REv. 751 (1969). 
employee protection was that no right to public employment existed. ${ }^{5}$ Holmes's often-quoted statement that a policeman fired for political activity "may have a constitutional right to talk politics, but he has no constitutional right to be a policeman," was applied universally. But in the 1950's and 1960's, in a series of cases invalidating loyalty tests for public school teachers, the Supreme Court began to undercut the general doctrine that public employees necessarily surrendered constitutional rights that could not otherwise be abridged merely by accepting employment. ${ }^{7}$ And in Pickering $v$. Board of Education, ${ }^{8}$ the Court held that the protection of those constitutional rights extended to protection against unjustified dismissal for public criticism of a government employer's policies. ${ }^{9}$

Pickering, a public school teacher, had written a letter to the editor of a local newspaper criticizing the school board for misrepresenting or failing to reveal the purposes for which the proceeds of a previous school bond issue were spent, after the school board had campaigned unsuccessfully for a subsequent bond issue. The Court held that Pickering's statements, although critical of his employer, were upon issues legitimately the subject of public attention, and were therefore entitled to the same basic constitutional protection as any citizen's comments upon public matters. ${ }^{10}$ Because the fact that he was employed by the school board was only tangentially and insubstantially involved in the subject matter of his letter, the Court held that Pickering's statements could not be a constitutional ground for his dismissal; they were either true or, if false, had not been made with knowledge or reckless disregard of their falsity, thus satisfying the "actual malice" standard enunciated in New York Times Co. v. Sullivan. ${ }^{11}$ But the Court also recognized that the state

${ }^{5}$ See, e.g., Board of Educ. v. Swan, 41 Cal.2d 546, 556, 261 P.2d 261, 268 (1953).

${ }^{B}$ McAuliffe v. New Bedford, 155 Mass. 216, 220, 29 N.E. 517 (1892).

' Keyishian v. Board of Regents, 385 U.S. 589, 605 (1967); see Baggett v. Bullitt, 377 U.S. 360 (1964); Cramp v. Board of Publ. Instruction, 368 U.S. 278 (1961); Shelton v. Tucker, 364 U.S. 479 (1960); Slochower v. Board of Higher Educ., 350 U.S. 551 (1956); Wieman v. Updegraff, 344 U.S. 183 (1952). See also Speiser v. Randall, 357 U.S. 513 (1958) (holding the denial of veterans' tax exemption for failure to subscribe to loyalty oaths unconstitutional).

8391 U.S. 563 (1968).

- See id. at 568 .

${ }^{10}$ Id. at 572-73. The Court drew no analytical distinction between disclosures of facts learned in the course of employment, with which this comment is primarily concerned, and statements of opinion based on publicly known facts, which may be the more usual form of citizens' speech protected by the first amendment. But Pickering's letter clearly included fact disclosures as well as statements of opinion, see id. at 575-78 (Appendix to Opinion of the Court), and later cases have applied the Pickering rule in situations primarily involving fact disclosures. See, e.g., Commonwealth ex rel. Rafferty v. Philadelphia Psychiatric Center, 356 F. Supp. 500 (E.D. Pa. 1973).

11391 U.S. at 569, 573-74, citing New York Times Co. v. Sullivan, 376 U.S. 254, 280 
has special interests in orderly school administration that might justify stricter regulation of speech by its employees despite their constitutional rights as citizens. ${ }^{12}$ While stating that it was neither appropriate nor feasible to lay down a general standard for predicting the situations in which a conflicting state interest would outweigh the employees' speech interest, ${ }^{13}$ the Court did indicate the limits of the balancing by suggesting the reasons it did not find such a conflict in Pickering's case.

For example, the Court noted that Pickering had no close working relationship with members of the school board that might have been adversely affected by his statements ${ }^{14}$ and that despite the likelihood that Pickering would be well informed concerning school matters because of his position, the facts he disclosed were not so within his personal knowledge that they would be difficult to rebut once they were disclosed..$^{15}$ The question of whether the existence of either of these situations would have required a different result in the case was expressly reserved. ${ }^{16}$ The Court held only that absent any such special interest in restricting disclosure, the government employee's public statements were to be judged by the standard applied to public statements generally, taking into account the strong interest of both the speaker and the public in fostering "free and open debate.""n

Despite the Pickering Court's express reluctance to set forth a precedent of broad applicability and its repeated disavowals of any judgment as to the sufficiency of the special restriction-justifying circumstances it suggested, its opinion has been taken as providing

(1964). See also Meehan v. Macy, 425 F.2d 469, 470-71 (1968), aff'd en banc, 425 F.2d 472 (D.C. Cir. 1969), modifying 392 F.2d 822 (D.C. Cir. 1968) (holding that the Times test, after Pickering, was the ultimate standard to be applied in public employee disclosure cases only where the employee's status in speaking was virtually that of a private citizen).

The Court was wary about applying the Times standard wholesale, since it had been enunciated in the context of a private citizen's defense to a libel suit by a public official, and the Court expressly reserved the question of whether a government employee's knowingly or recklessly false statements might still be protected by the first amendment if no harm could be shown to have resulted from them. 391 U.S. at 574 n.6.

12391 U.S. at 568.

${ }^{13} \mathrm{Id}$. at 569 .

"Id. at 569-70.

is Id. at 572. Other special circumstances, including great need for confidentiality, need for co-worker harmony and discipline, and the fact that an employee's statements are so without foundation as to call his competence into question, were suggested and dismissed by the Court in summary fashion. Id. at 570 n. 3,573 n.5, 574 n.6. See also Donahue v. Staunton, 471 F.2d 475, 481 (7th Cir. 1972), cert. denied, 410 U.S. 955 (1973) (enumerating all of the suggestions as stating the limits of the Pickering rule).

16391 U.S. at 570 \& n.3, 572.

17 Id. at $571-72,573$. 
specific guidelines for evaluating government imposed sanctions of employee disclosures. The list of special circumstances has been interpreted as either suggestive or exhaustive, and with a variety of contradictory results in particular cases. ${ }^{18}$ Conflicting interpretations have focused in particular on the Pickering Court's first observation-that, in view of plaintiff's remote working relationship with the school board, "no question of maintaining either discipline by immediate superiors or harmony among co-workers" was presented. ${ }^{19}$

In Watts $v$. Seward School Board,,$^{20}$ the Alaska Supreme Court upheld the dismissal of several teachers for their allegedly disruptive public charges of maladministration and improper practices by the school superintendent. The court viewed the state's interest in regulating this type of disclosure as significantly different from that involved in the regulation of the speech of citizens in general ${ }^{21}$ since the disclosure was detrimental to harmony among the discharged teachers and their co-workers and to the efficient operation of the schools. ${ }^{22}$

A federal district court in Pennsylvania evaluated the disharmony factor more rigorously and came to a different conclusion in Commonwealth ex rel. Rafferty $v$. Philadelphia Psychiatric Center. ${ }^{23}$ The defendant mental health agency justified dismissal of Rafferty, a psychiatric nurse, on the grounds of "staff anxiety" cre-

${ }^{18}$ Courts have, for example, taken different views of how disruptive repercussions should affect the protection afforded the employee's speech. Some see the disruption element as decisive in the state's favor. See, e.g., Jannetta v. Cole, 493 F.2d 1334, 1337 (4th Cir. 1974) (interference with efficiency of public services is the initial determination); Birdwell v. Hazelwood School Dist., 491 F.2d 490, 494 (8th Cir. 1974) ("potential" disruption adequate grounds for dismissal). Others reject the argument that the disruption factor is conclusive in itself. See, e.g., Hostrop v. Board of Junior College Dist. No. 515, 471 F.2d 488, 492 (7th Cir. 1972), cert. denied, 411 U.S. 967 (1973) (speech must cause "substantial" disruption or hinder the functioning of the state); Los Angeles Teachers Union v. Los Angeles City Bd. of Educ., 71 Cal. 2d 551, 561, 455 P.2d 827, 833, 78 Cal. Rptr. 723, 728 (1969) (disharmony from clash of opposing viewpoints cannot support dismissal). An intermediate position is taken by courts which stress the fact that all the Pickering factors must be considered. See, e.g., Mailloux v. Kiley, 448 F.2d 1242, 1243 (1st Cir. 1971) (guidelines rejected in favor of case-by-case inquiry); Pred v. Board of Pub. Instr., 415 F.2d 851, 858 (5th Cir. 1969) (factors favoring either side relevant).

19391 U.S. at 570.

${ }^{20} 454$ P.2d 732 (Alas. 1969), cert. denied, 397 U.S. 921 (1970). Watts had been remanded twice by the United States Supreme Court, the second time for further consideration in light of Pickering. Watts v. Seward School Bd., 391 U.S. 592 (1968), vacating and remanding 421 P.2d 586 (Alas. 1967).

21454 P.2d at 733.

22 Id. at 735 .

2356 F. Supp. 500 (E.D. Pa. 1973). 
ated by her disclosure of substandard conditions, ${ }^{24}$ which in turn led to an "antitherapeutic situation" in the inpatient unit because the staff's anxiety could be felt by the patients. In restoring Rafferty to her position, the court held that "[t] stop at the hospital door. A hospital . . . may not . . . be permitted to mask its arbitrary suppression of protected speech behind claims that such speech creates an 'anti-therapeutic situation' when no ill effect on patient care has been shown." 25 The court admitted that staff anxiety might have resulted from the disclosures, but held that "staff anxiety over working with someone who is critical and outspoken, who adds to the dialogue that the First Amendment was designed to foster and protect," could not furnish a justification for stifling an employee's freedom of expression. ${ }^{26}$

The court in Watts placed great emphasis on the fact that the superintendent against whom the appellants' statements were directed was a person with whom they had daily contact in the course of their work. ${ }^{27} \mathrm{By}$ unduly emphasizing the state interest in maintaining the disciplinary authority of superior officials and by applying a low standard of disruptive or disharmonious effect, the Watts court may well have under-cut the rights conferred on public employees by Pickering in the context in which they are most useful and most necessary. Because the most readily apparent misconduct will often be that of a co-worker or immediate superior, the fact that the disclosure may potentially be disharmonious or disruptive should not be sufficient in itself to justify sanctions against the disclosing employee. ${ }^{28}$

The Supreme Court ruled in Pickering that the school board had not demonstrated the harmfulness of the letter upon which it based its dismissal action since that letter was greeted by everyone

${ }^{24}$ She complained in a newspaper interview that the staff failed to protect patients from homosexual abuse and sexual exploitation both by other patients and by outsiders working on the grounds, that they allowed patients to keep medication in their rooms, and that they left signed blank prescription forms to be filled out by nurses on weekends. Id. at 503 .

${ }_{25}$ Id. at 508 .

2* Id. See also Los Angeles Teachers Union v. Los Angeles City Bd. of Educ., 71 Cal.2d 551, 558-59, 455 P.2d 827, 831, 78 Cal. Rptr. 723, 727 (1969) (holding that the dismissal of a teacher who circulated a petition could not be justified by the "unrest . . . inevitably generated by the expression of ideas which are controversial").

27 Watts v. Seward School Bd., 454 P.2d 732, 735 (Alas. 1969).

28 See, e.g., Hostrop v. Board of Junior College Dist. No. 515, 471 F.2d 488, 492-93 (7th Cir. 1972), cert. denied, 411 U.S. 967 (1973) (holding that discharge of professor who circulated controversial memorandum could not be justified on mere argument that his working relationship with the memorandum's target made disruption possible, without showing that the public employer's "functions are being substantially impeded by the employee's statements"). 
save the board "with massive apathy and total disbelief."29 Justice White, in a separate opinion, took issue with this emphasis on detrimental repercussions. In his view, once the Court had determined that Pickering's statements were neither knowingly nor recklessly false, the question of harm was "clearly irrelevant." 30

Justice White may have been disturbed by the prospect that subsequent cases would fall outside the Pickering rule if a different finding of fact with respect to harmful effects-equated with effectiveness-were reached. ${ }^{31}$ The approach of the Alaska court in Watts seems to justify that concern. The court in that case concluded with a minimum of analysis that the letter in question was not met "with massive apathy and total disbelief" and that the state had a legitimate interest in preventing disclosures which resulted in disturbances to the school system. ${ }^{32}$ As the dissent pointed out, the majority equated disturbances with harm, but failed to find any actual harm to the teaching process itself or the administration of the schools. ${ }^{33}$ Given the focus of the first amendment on fostering vital public debate, the standard of proof of harm to special state interests in harmony and discipline must be substantially higher. ${ }^{34}$

In some circumstances the potential danger in permitting disclosure is very great. Restraints upon disclosures by government employees are easier to justify when, for example, the government asserts considerations of public safety or national security. Although "policemen ... a are not relegated to a watered-down version of constitutional rights,"35 courts in disclosure cases have distinguished policemen from other public servants because of the importance of internal discipline in the police force. ${ }^{36}$ The balance has

29391 U.S. at 570.

${ }^{30}$ Id. at 583 (White, J., concurring in part and dissenting in part). Justice White also took issue with the Court's "gratuitous suggestion" that when statements are found to be knowingly or recklessly false, the first amendment may still protect them unless they are shown or can be presumed to have caused harm. Id.; see note 11 supra; cf. Garrison v. Louisiana, 379 U.S. 64, 75 (1964).

${ }^{31}$ Cf. Note, The First Amendment and Public Employees: Times Marches On, 57 Geo. L.J. 134, 155 (1968).

${ }_{32}$ Watts v. Seward School Bd., 454 P.2d 732, 735 (Alas. 1969).

${ }^{33}$ Id. at 742 (Rabinowitz, J., dissenting).

${ }^{34}$ See text and notes at notes $17,26,28$ supra.

${ }^{35}$ Garrity v. New Jersey, 385 U.S. 493, 500 (1967). See also Muller v. Conlisk, 429 F.2d 901 (7th Cir. 1970); Flynn v. Giarrusso, 321 F. Supp. 1295 (E.D. La. 1971).

${ }^{36}$ The paramilitary structure characteristic of police departments is often offered in support of this position. See Muller v. Conlisk, 429 F.2d 901, 904 (7th Cir. 1970). See also Brukiewa v. Police Comm'r., 257 Md. 36, 263 A.2d 210 (1970); In re Gioglio, 104 N.J. Super. 88, 248 A.2d 570 (Middlesex County Ct. 1968). For a comprehensive treatment of the first amendment rights of the police officer, see Note, The Policeman: Must He Be a Second-Class Citizen With Respect to His First Amendment Rights? 46 N.Y.U.L. REv. 536 (1971). 
been consciously tipped in that context to favor the government's interest in efficient and effective public service at the expense of first amendment freedoms.

In other cases in which the threat of harm from disclosure was of sufficient magnitude, the government has been permitted to impose a system of prior restraint to prevent its employees from issuing public statements, even though prior restraint of the press under similar circumstances would not meet constitutional standards. ${ }^{37}$ Thus, in United States $v$. Marchetti, ${ }^{38}$ in which the Central Intelligence Agency sought to restrain a former employee from publishing a book about the agency, the Fourth Circuit affirmed an injunction against him, ${ }^{39}$ acknowledging that the government had met its heavy burden of showing potential harm. ${ }^{40}$ The decisive factors in the court's view were the "position of trust and confidence" held by Marchetti while he acquired the secret information that he sought to disclose and the Government's need for secrecy in the intelligence area. ${ }^{41}$

The right of government employees to comment publicly on matters of public concern has its basis in the first amendment guarantee of freedom of speech, as does the right of any citizen to comment on public affairs. Although the Pickering Court recognized

${ }^{37}$ Compare New York Times Co. v. United States, 403 U.S. 713, 714 (1971), with United States v. Marchetti, 466 F.2d 1309, 1311 (4th Cir.), cert. denied, 409 U.S. 1063 (1972). Prior restraint is allowed in part because it is more effective in preventing disclosures than the threat of subsequent punishment. See United States v. Marchetti, supra at 1317. In some circumstances, there may be no subsequent opportunity to impose sanctions. It has been argued, for example, that the bombshell revelation of American policymaking concerning Vietnam released by Daniel Ellsberg after he had left the employment of a government contractor could not be reached under existing federal law. See Nimmer, National Security Secrets v. Free Speech: The Issues Left Undecided in the Ellsberg Case, 26 Stan. L. Rev. 311 (1974).

${ }^{38} 466$ F.2d 1309 (4th Cir.), cert. denied, 409 U.S. 1063 (1972).

33 The government, in seeking to enforce the terms of the secrecy agreement signed by Marchetti, obtained an order from the district court that enjoined him from releasing "any writing, fictional or nonfictional, relating to the Agency or to Intelligence" without prior approval by the CIA. Id. at 1311 .

40 Marchetti's major line of defense rested on the Supreme Court ruling in New York Times Co. v. United States, 403 U.S. 713 (1971), which imposed a heavy burden on the government in seeking to justify any system of prior restraints of expression. Id. at 714. In that case, the government failed to overcome the heavy presumption against the constitutional validity of an order enjoining the New York Times and the Washington Post from publishing the classified study on American policy in Vietnam known as the Pentagon Papers.

"It has also been argued that the Marchetti court may have based its ruling on the nature of the materials involved and the extent of the public's right to that information; the Fourth Circuit may have found less compelling an interest in the disclosure of Marchetti's book than the interest that existed in the New York Times case, 403 U.S. 713 (1971), in allowing the information contained in the Pentagon Papers to flow to the public. See Note, 51 N.C.L. REv. 865, 869-70 (1973). 
this common constitutional ground, it also recognized that the right could be outweighed by governmental interests peculiar to the employment relationship. The Court eschewed any general standard that could be applied in evaluating a public employee's disclosure; instead, it sketched out the limits of the balance by suggesting relevant governmental interests that did not exist in that case and might not even be determinative in a case in which they did appear. Courts have subsequently applied the Pickering dicta either simplistically or conscientiously, with unpredictable results. Thus, the scope of the first amendment right of public employees to comment on public matters remains ill-defined and may depend upon the balance struck by a particular court in a particular case.

2. The First Amendment Right to Petition. When the government employee seeks protection for a disclosure that takes the form of a petition directed to an agency superior or to a congressman rather than a statement to the public or the press, the constitutional provision properly invoked is the first amendment right of petition for redress of grievances. Very few cases have involved a consideration of the scope of this constitutional protection against employment sanction, but those few have indicated that the protection of the right to petition may be broader than that afforded for public statements under Pickering.

In Swaaley $v$. United States, ${ }^{42}$ decided one year before Pickering, the Court of Claims held that a navy shipyard mechanic who was dismissed for having complained to the Secretary of Labor about improper promotion procedures was entitled to damages. ${ }^{43}$ The dismissal had been based on a finding that Swaaley, who bore the burden of proof at his discharge hearing, had failed to corroborate the allegations of graft and favoritism he made in his letter. ${ }^{44}$ The court refused to permit dismissals to be based on such a standard because of the danger that employees' beliefs of agency wrongdoing would be suppressed by self-censorship, to the detriment of the general public interest in effective government. ${ }^{45}$ The court applied the New York Times standard instead, ${ }^{46}$ holding that the employee was entitled to first amendment protection against sanction even for false and defamatory statements, so long as they were made in the course of a petition submitted to an agency supe-

\footnotetext{
${ }^{42} 376$ F.2d 857 (Ct. Cl. 1967).

${ }^{43} \mathrm{Id}$. at 867 .

"Id. at $860-61$.

${ }^{45} \mathrm{Id}$. at 861-62.

${ }^{46} \mathrm{Id}$. at 863 .
} 
rior ${ }^{47}$ who the employee believed had the power to redress his grievance, ${ }^{48}$ and so long as the statements were not made with knowledge or reckless disregard of their falsity. ${ }^{49}$

Subsequent cases in the Court of Claims as well as in other courts have referred to Swaaley for the proposition that only the New York Times standard limits the right of government employees to petition for redress of grievances through agency channels, ${ }^{50}$ and have indicated further that this holding is consistent with Pickering. ${ }^{51}$ That test, however, would provide potentially greater protection for employees who disclose wrongdoing by petition than for those who make public statements disclosing the same wrongdoing. Under Pickering, the New York Times test is only applied in cases in which disclosures are not different from those a private citizen would make, or in which special interests related to the speaker's employment relationship are not affected. ${ }^{52}$ That is, even if a disclosure were not maliciously made, the Supreme Court's opinion in Pickering might allow sanctions to be imposed because of harm to governmental interests in confidentiality, discipline, harmony, or loyalty. ${ }^{33}$ But if the New York Times standard is the only standard to be applied in evaluating governmental sanctions under the first amendment guarantee of freedom of petition, a single disclosure that is deleterious to the governmental interests enumerated in Pickering might be protected if it took the form of a letter to an agency superior but not if it took the form of a letter to a newspaper editor. ${ }^{54}$

47 The court specifically declined to consider the standard for petitions directed to members of Congress, which are protected under a broadly worded statute. Id. But the constitutional protection for such petitions should certainly be no less than that applied in Swaaley, and the statute may provide even more. See note 100 infra.

4" See Ruderer v. United States, 412 F.2d 1285, 1291 (Ct. Cl. 1969), cert. denied, 398 U.S. 914 (1970) (explaining prior holding in Swaaley).

4. Swaaley v. United States, 376 F.2d 857, 863 (Ct. Cl. 1967), citing New York Times Co. v. Sullivan, 376 U.S. 254, 280 (1964).

so See, e.g., Meehan v. Macy, 425 F.2d 463, 471 \& n.12 (D.C. Cir. 1968), aff'd en banc, 425 F.2d 472 (D.C. Cir. 1969); Ianarelli v. Morton, 327 F. Supp. 873, 886-88 (E.D. Pa. 1971); Ruderer v. United States, 412 F.2d 1285, 1290 (Ct. Cl. 1969), cert. denied, 398 U.S. 914 (1970). See also Note, The First Amendment and Public Employees: Times Marches On, 57 Geo. L.J. 134, 144 (1968).

${ }^{51}$ See Meehan v. Macy, 425 F.2d 469, 471 (D.C. Cir. 1968), aff'd en banc, 425 F.2d 472 (D.C. Cir. 1969); Jackson v. United States, 428 F.2d 844, 846 (Ct. Cl. 1970).

52 See text at notes 10-13 supra.

53 See text and notes at notes 12-17 supra.

st In one respect, the Swaaley rule is not consistent with Pickering's application of the New York Times test. The Supreme Court indicated that its holding in Pickering was based in part on the remoteness of Pickering's public statements from his employment relationship and their similarity to comments that might have been made by members of the general 
This implication of the Swaaley holding might be justified on the ground that the level of harm to governmental interests caused by petitions through agency channels can be presumed to be too low in any case to justify the imposition of sanctions on an employee's petition. ${ }^{55}$ Taken generally, this proposition may seem correct. No governmental interests in intra-agency confidentiality are breached by a petition, and an agency head is able to respond to a petition complaining of wrongdoing in the manner that seems most appropriate in light of his knowledge of other relevant facts and of his commitment to the agency's best interests. As the court in Swaaley noted, "a petition, properly so-called, that has never left a Department need do no harm." 56 The District of Columbia Circuit recently indicated a similar view in Ring $v$. Schlesinger, ${ }^{57}$ in which it held that the record in the case did not support the district court's conclusion that all of the governmental interests suggested in Pickering were present. ${ }^{58}$ The court of appeals noted, referring to Swaaley, that the employee in Ring had submitted her grievance only to a few of her superiors and one outsider who had not responded, thus differentiating the situation from Pickering's published letter. ${ }^{59}$

The presumption seems dubious, however, when viewed in light of some of the specific interests noted in Pickering. For example, the discipline of agency employees and harmony among coworkers might be affected as much by a disclosing petition as by a public statement. ${ }^{60}$ One judge dissented in Ring on the ground that the complaining employee's statements, though not widely broadcast, did have the definite effect of aggravating friction and discord among her co-workers. ${ }^{61}$

public. See text at note 11 supra. When a government employee petitions a superior for redress of a grievance, however, his statements are likely to be directly related to his employment. If the rationale for applying the Times test in Pickering were limited to the public citizen analogy, the Swaaley rule of applying it in every petition case would not seem justified.

${ }^{5}$ See T. Emerson, The System of Freedom of Expression 570 (1970); cf. Note, Dismissals of Public Employees for Petitioning Congress: Administrative Discipline and 5 U.S.C. Section 652(d), 74 YALE L.J. 1156, 1169-70 (1965) [hereinafter cited as YALE NoTE].

so 376 F.2d at 863 . See also id. at 862 (suggesting that harm would only result from dissemination of a petition, and that the fault lies with the recipient rather than the petitioner if such harm results).

${ }^{57} 502$ F.2d 479 (D.C. Cir. 1974).

${ }^{58}$ Id. at 488.

58 Id. at 489.

${ }^{80} C f$. Yale Note, supra note 55, at 1169-70.

61 502 F.2d at 494-95 (Robb, J., dissenting). But see Ianarelli v. Morton, 327 F. Supp. 873,888 (E.D. Pa. 1971) (holding that solicitation of petitions was subject only to the Swaaley test even though actual "disaffection and dissension" was shown). 
The Swaaley rule thus might be read as guaranteeing broader protection than Pickering would require for public employee disclosures of agency wrongdoing that take the form of petitions rather than statements to the public or the press. If this interpretation of Swaaley is authoritatively adopted, intra-agency petitions would be the more effective means of reform and disclosure by government employees. ${ }^{62}$ The public interest in the self-policing of agency misfeasance will be given precedence over the agency's interests in efficient operation insofar as dissention or disharmony resulting from a petition is not permitted to justify sanction. Of course, this higher level of protection would apply only to the specific class of disclosures that can be defined as petitions for redress of grievances. ${ }^{63}$ When a petition is accompanied by other intra- or extraagency statements or actions, or when the Swaaley-New York Times standard is not met because the petition is malicious, ${ }^{64}$ the disclosing employee's discharge may be justified.

3. First Amendment Protection Against Vague or Overbroad Nondisclosure Rules. A final constitutional doctrine that creates substantive protection for government employee disclosures is the two-edged prohibition against rules that are vague or overbroad. The overbreadth doctrine has developed to protect the exercise of first amendment rights that might otherwise be inhibited. It has been applied in a variety of situations under the rationale that a rule that on its face prohibits both protected and unprotected first amendment activity has a deterrent impact on persons who contemplate prohibited activity but are uncertain whether they can raise the first amendment's protection successfully against the application of the rule to them. ${ }^{65}$ The vagueness doctrine is closely related, but the inhibiting effect of a vague rule stems from uncertainty as to what activity the rule prohibits. ${ }^{66}$ Thus, even plaintiffs whose

62 There may be cases in which petition for redress of grievances is an ineffective or inappropriate vehicle for making a particular disclosure. Public statements designed to bring public pressure to bear on the agency when the employee seeks to correct what he perceives as agency wrongdoing would, of course, be subject to Pickering standards.

${ }^{63}$ It would not extend, for example, to statements outside channels made by an employee who also files a petition making the same disclosure. (1970).

"See Ruderer v. United States, 412 F.2d 1285 (Ct. Cl. 1969), cert. denied, 398 U.S. 914

is See Broadrick v. Oklahoma, 413 U.S. 601, 615 (1973); NAACP v. Button, 371 U.S. 415, 432-33 (1963); Note, The First Amendment Over-breadth Doctrine, 83 HaRv. L. Rev. 884, 853 (1970) [hereinafter cited as HaRvard NoTE].

w The vagueness doctrine, which has its roots in due process concepts of fair notice, is distinguishable from overbreadth in the abstract; the question for an individual confronted by a vague statute is whether his action is prohibited by the statute, while the question raised by an overbroad statute is whether the individual's action, though clearly prohibited by the 
activities might constitutionally be restricted by a properly drawn rule may avoid that restriction in some cases where the rule under which they are sanctioned can be attacked as vague or overbroad. A government employee making a disclosure that would justify dismissal or other sanction under Pickering or Swaaley, then, might still be constitutionally protected from any retaliatory action imposed under a vague or overbroad nondisclosure rule.

In Muller $v$. Conlisk, ${ }^{67}$ for example, a detective of the Chicago Police Department challenged a departmental rule that prohibited all statements by policemen that were "derogatory to the Department or any member or policy of the Department." Circuit invalidated the rule and the sanction that had been imposed on Muller for his statements to the press concerning the Department's Internal Inspection Division. ${ }^{69}$ The court took note of the Department's argument that because Muller was a police officer, the interests of his employer in restricting his speech were greater than those recognized in Pickering, but concluded that the additional interest only affected the balancing to be undertaken in a particular case and did not eliminate Muller's right to criticize his employer entirely.$^{70}$ Whether or not Muller's particular statements would have survived the ultimate balancing under Pickering, the departmental rule was unconstitutional on its face because it prohibited all criticism. ${ }^{71}$

The vagueness doctrine was the ground for the Seventh Circuit's decision in Bence $v$. Breier, ${ }^{72}$ a case involving the reprimand of two Milwaukee police officers for making false statements in a letter critical of certain Milwaukee Police Department employee compensation practices. The disciplined employees, officers of the policemen's union, had sent the letter to the city's labor negotiator and posted it on union bulletin boards in connection with a collective bargaining agreement term currently under negotiation. The Department's reprimand was imposed under a departmental rule

statute, would be protected from sanction by its constitutional status. In cases involving first amendment activity, the application and rationale for the two doctrines may merge. See Keyishian v. Board of Regents, 385 U.S. 589, 609 (1967); NAACP v. Button, 371 U.S. 415, 432-33 (1963); HaRvard Note, supra note 65, at 871-75.

${ }^{87} 429$ F.2d 901 (7th Cir. 1970).

(8) Id. at 902.

${ }^{89}$ Id. at 902-03.

${ }^{70} \mathrm{Id}$. at 904 .

${ }^{71}$ Id. But cf. Partnow v. Moran, 359 F. Supp. 519 (D. Del. 1973) (district court, presented with vagueness and overbreadth challenges to a rule under which disclosing employee was dismissed, abstained pending potentially narrowing interpretation of rule in state court suit).

32501 F.2d 1185 (7th Cir. 1974). 
prohibiting conduct "unbecoming a member and detrimental to the service." 73 The court held that since this rule was unnecessarily vague in its scope, and since it therefore might apply to activities that involved speech by government employees, it unconstitutionally deterred protected speech to the same extent as if it were clear in its scope but overbroad. ${ }^{74}$

For federal civil service employees and many state governmental employees, the statutes generally covering sanctions for improper behavior require the government employer to show "cause" or "just cause" or the like. ${ }^{75}$ The Supreme Court recently considered vagueness and overbreadth challenges to the federal statute in Arnett $v$. Kennedy. ${ }^{76}$ Despite the fractionalization of the Court on the separate issue of the procedures necessary for dismissing a federal employee under the statute, ${ }^{77}$ five Justices joined Justice Rehnquist in holding that the standard of "such cause as will promote the efficiency of the service" was neither unconstitutionally vague nor overbroad. ${ }^{78}$ Justice Rehnquist's opinion first stressed the difficulties of defining with great specificity a single standard of conduct for "myriad different federal employees performing widely disparate tasks."79 Just as the Court in Pickering had refrained from laying down a general constitutional standard that would cover all situations involving speech by government employees, ${ }^{80}$ Justice Rehnquist refused to require that Congress lay down a statutory standard that would deal comprehensively with all instances of questionable conduct by federal employees. ${ }^{81}$ Pointing out that the Civil Service Commission had given some general interpretative guides $^{82}$ and that the specific agency employer involved had pro-

Id. at 1187 .

"See id. at 1190.

${ }^{75}$ See text and notes at notes 104-07, 126-27 infra.

${ }^{76} 413$ U.S. 134 (1974). Kennedy, a nonprobationary civil service employee, had been dismissed from his position in the Office of Economic Opportunity (OEO) after accusing the OEO Regional Director and a co-worker of attempting to bribe a potential OEO grantee. The OEO charged that the statements were slanderous and that their utterance caused disharmony in the office to which Kennedy was assigned. Id. at 175 (White, J., concurring in part). infra.

7 For a discussion of the Court's due process holding, see text and notes at notes 151-58

77 416 U.S. at 158-63 (opinion of Rehnquist, J., joined by Burger, C.J., and Stewart, J.); id. at 164 (opinion of Powell, J., joined by Blackmun, J.); id. at 177 (White, J., concurring in part).

"Id. at 159.

See text at note 13 supra.

^ 416 U.S. at 161. See also Civil Serv. Comm'n v. Letter Carriers, 413 U.S. 548, 578-79 (1973).

\&2 416 U.S. at 160; see id. at 171-72 \& n.2 (White, J., concurring in part). 
vided for advisory assistance by its own general counsel's office if an employee was uncertain as to the statute's meaning, ${ }^{83}$ Justice Rehnquist held that the "cause" standard was not so vague as to be unconstitutional. Justice Rehnquist also held that the statute, which was designed to give federal employees protection that they had previously lacked rather than to impose sanctions for certain misconduct, could not be interpreted to authorize discharge for constitutionally protected conduct; ${ }^{84}$ it was not overbroad.

Arnett would thus seem to limit the usefulness of the vagueness and overbreadth doctrines in challenging sanctions for employment related disclosures that have been imposed under broadly worded rules. The government employer might argue that, as in Arnett, greater specificity in defining sanctionable misconduct is impossible. In many cases involving general misconduct statutes, it might also be possible to argue that the rule should be construed not to apply at all to constitutionally protected speech. Muller and Bence, however, give some indication of what protection might still be available after Arnett. In Bence, the court emphasized the lack of necessity for the vagueness of the "unbecoming a member" standard, pointing to the specifically enumerated forms of misconduct that were also made grounds for sanction in the same rule in which the catch-all category was stated. ${ }^{85}$ It would seem that in most cases involving rules promulgated by a particular agency or department, in contrast with the general civil service statute considered in Arnett, greater specificity would be possible and broadly worded misconduct rules might more readily be held unconstitutionally vague. Furthermore, when that greater susceptibility to specific rule-making is exercised clearly to prohibit a broad range of speech activities, as in Muller, the Arnett argument for interpreting a rule to avoid an overbroad application will not be convincing. It would seem, then, that there remain areas, especially those involving rules of particular agencies and departments, in which overbreadth and vagueness claims might protect employee disclosures even more broadly than Pickering.

\section{B. Statutory Protections}

Legislative enactments protecting the disclosing employee delineate somewhat more precisely the scope of executive discretion

83 Id. at 160.

${ }^{84}$ Id. at 162.

${ }^{85}$ Bence v. Breier, 501 F.2d 1185, 1189 (7th Cir. 1974). 
in employment sanctions that may remain unrestricted by the constitutional doctrines. The statutes have the potential for addressing narrower sets of circumstances more specifically, and thus are potentially capable of laying down the comprehensive standard that the Supreme Court eschewed in Pickering. Legislatures might also simply grant broader statutory protections for disclosing employees than the first amendment requires.

One narrow area of federal employee disclosure-that involved when an employee petitions Congress-is given strict statutory protection $^{86}$ against being "interfered with or denied" under section 7102 of title 5 of the United States Code. ${ }^{87}$ Enacted as part of the Lloyd-LaFollette Act in $1912,{ }^{88}$ the statute was originally intended to reverse President Taft's "gag rule," which prohibited civil servants from communicating information concerning any legislative matter to Congress without the consent of their department heads. ${ }^{89}$ According to its sponsor, the Act's purpose was to counter the power of executive officials "to withhold information and suppress the truth or to conceal their official acts.",90

Neither Congress nor the state legislatures, however, have addressed the problem of fact disclosures specifically; the matter is dealt with, for the most part, under generalized provisions that encompass all categories of employee misbehavior and unfitness. As a result, unpredictability and unequal treatment continue to plague this area of public employee rights.

Judicial interpretations of section 7102 and its predecessor have sketched the limits of the protection the statute provides. In 1961, the District of Columbia federal district court granted summary judgment for an employee seeking reinstatement after he was discharged for circulating a petition among his co-workers to be presented to Congress. ${ }^{91}$ The court thought that the statute would pro-

84 This protection, of course, is in addition to that provided under the first amendment guarantee of freedom to petition for redress of grievances. See text at notes $42-62$ and note 47 supra.

${ }^{87}$ The right of employees, individually or collectively, to petition Congress or a

Member of Congress, or to furnish information to either House of Congress, or to a committee or member thereof may not be interfered with or denied.

5 U.S.C. $\S 7102$ (1970). See also 18 U.S.C. $\S 1505$ (1970) (making intimidation of witnesses in Congressional investigations punishable by substantial fine and imprisonment).

${ }^{* 8}$ Act of Aug. 24, 1912, ch. 389, § 6, 37 Stat. 555 (codified at 5 U.S.C. $\S 652$ (d) (1964)). Section 652(d) was later recodified as section 7102 in substantially identical terms. Act of Sept. 6, 1966, Pub. L. No. 89-554, 80 Stat. 523, amending 5 U.S.C. 8 652(d) (1964) (codified at 5 U.S.C. $\$ 7102$ (Supp. IV, 1969)).

* Exec. Order No. 1142, Nov. 26, 1909, reprinted in 48 Cong. Rec. 4513 (1912).

s0 48 Cong. Rec. 10671 (1912) (remarks of Representative Lloyd).

" Steck v. Connally, 199 F. Supp. 104, 105 (D.D.C. 1961). 
tect such activity even if the employee acted unreasonably or made false statements in his petition, ${ }^{92}$ but also indicated that the government might interfere with the employee's petitioning if it could show that "serious disruption of work and a substantial loss of time" had occurred..$^{93}$ The District of Columbia Circuit later affirmed, in Turner $v$. Kennedy, ${ }^{94}$ the discharge of a civil service employee who had made "false, irresponsible and unjustified" statements in letters he had written to Congressmen, which were found by the Civil Service Commission to have demonstrated his unsuitability for employment and to have impaired the efficiency of his agency. One judge dissented, ${ }^{95}$ criticizing the court's implicit deference to the government's assertion of a broad limitation on the employee's statutory right to petition Congress, ${ }^{96}$ and suggested that the case should have been remanded for the application of only the "actual malice" standard of New York Times Co. $v$. Sullivan. ${ }^{97}$

As under the interpretation of Swaley discussed above in the context of the constitutional protection of petitions within agency channels, ${ }^{98}$ this interpretation of section 7102 would provide potentially more protection for the disclosing employee than he would receive under the Pickering rule. At least one commentator has agreed with the Turner dissenter that section 7102 petitions should be completely protected so long as the New York Times standard is met; any discharge or sanction of an employee who petitions Congress should be based only on harm to governmental interests caused by other actions of the employee which assertedly are likely to exist in most instances..$^{99}$ Support for this position is found both in Congress' specific and unqualified mandate in the statute itself

${ }^{92}$ The court noted that "[i]t can be vexatious and annoying at times if the employee acts unreasonably, but the statute contains no limitation." Id.

${ }^{23} \mathrm{Id}$.

94 332 F.2d 304 (D.C. Cir.) (mem.), cert. denied, 379 U.S. 901 (1964).

${ }^{95}$ See id. (Fahy, J., dissenting).

96 Id. at 305. The Civil Service Commission Board of Appeals and Review had held that the statutory right to petition Congress could be lost if "the employee's conduct consituted an abuse of the right and went beyond the scope of permissible activity contemplated by Congress in enacting this legislation, and ... thereby caused the agency immediate and substantial harm." See YALE NoTE, supra note 55, at 1157 (quoting from the administrative record submitted by the government to the court of appeals in Turner). As thus stated, of course, the limitation does little more than define a balance between the interests of employees that Congress intended to protect and the interests of the government that might be harmed by petition disclosures. Cf. notes 13-16 supra.

${ }_{97} 332$ F.2d at 307, citing New York Times Co. v. Sullivan, 376 U.S. 254, 280 (1964); see text at note 11 supra.

${ }^{98}$ See text and notes at notes 42-62 supra.

39 Yale Note, supra note 55, at 1169; see Turner v. Kennedy, 332 F.2d 304, 307 (D.C. Cir.), cert. denied, 379 U.S. 901 (1964) (Fahy, J., dissenting). 
and in the argument that petitions directed to Congress are generally less likely to affect governmental interests in loyalty, discipline and harmony than are public statements. ${ }^{100}$

No court has yet adopted this broad interpretation of the protection afforded by section $7102 .{ }^{101}$ In Ruderer v. United States, ${ }^{102}$ the most recent case to consider the infrequently invoked statute, the Court of Claims was required to go no further than to indicate the lowest common denominator of the opinions in Turner, stating in dicta that section 7102 at least did not provide an unlimited privilege for knowingly false and malicious statements. ${ }^{103}$ If this were held to be the exclusive limitation on petitions to Congress, section 7102 would provide potentially broader protection for a narrow class of employee disclosures than Pickering itself would require.

The statutory guide for treating the remainder of federal disclosures not taking the form of petitions to Congress is found in another part of the Lloyd-LaFollette Act, now codified as sections 7501(a) and 7512(a) of title 5 of the United States Code. ${ }^{104}$ Those sections provide, respectively, that no civil service employee shall be removed or suspended and no "preference eligible"105 civil service employee shall be subjected to "adverse action," 106 except "for such cause as will promote the efficiency of the service."107

Although the Supreme Court held in the Arnett case that this standard was not unconstitutionally vague in light of the vast variety of federal civil service employees and job situations for which it was intended to provide protection, ${ }^{108}$ the cause requirement of

100 YALE NOTE, supra note 55, at 1167-70. The note argues that harm to interests in coworker harmony and employee discipline are even less likely than would be true for intraagency petitions, which may involve direct confrontation with a culpable superior or going over the head of such a superior within the agency with disruptive repercussions.

${ }^{101}$ But cf. Swaaley v. United States, 376 F.2d 857, 863-65 (Ct. Cl. 1967) (applying the New York Times standard to a petition not covered by section 7102 , but suggesting that the Turner decision was not inconsistent).

102412 F.2d 1285 (Ct. Cl. 1969), cert. denied, 398 U.S. 914 (1970).

${ }^{103}$ Id. at 1292. The court found that the employee's discharge was based on statements other than those he had made in the few letters he had sent to Congress. Id.

iss 5 U.S.C. $\$ \$ 7501(\mathrm{a}), 7512$ (a) (1970).

les Preference eligible employees are those who have completed probationary or trial periods of employment, but do not include cabinet members and others whose appointment is required to be confirmed by the Senate. Id. $\$ 7511(1)$.

106 Adverse actions include removal, suspension for more than 30 days, furlough without pay, and reduction in rank or pay. Id. $\S 7511(2)$.

${ }^{107} I d . \$ \$ 7501(\mathrm{a}), 7512(\mathrm{a})$. The cause requirement does not apply to dismissals of employees deemed "necessary in the interests of national security" by an agency head. Id. $\S \S 7501(\mathrm{c}), 7512(\mathrm{c}), 7532(\mathrm{a})$.

${ }^{108}$ See text at note 78 supra. Justice Marshall, dissenting, felt that the standard was 
sections 7501(a) and 7512(a) adds little to the definition of the scope of protected employee disclosures. In holding that section 7501(a) was not overbroad on its face, the Court in Arnett indicated that it could not be interpreted as justifying dismissal for constitutionally protected speech, and thus that it provided no less protection than the first amendment under Pickering. ${ }^{109}$ It seems unlikely that section 7501(a) itself expands the scope of substantive protection, however, since harm to governmental interests that would justify dismissal of a disclosing employee under Pickering would seem always to satisfy the "promote the efficiency of the service" standard as well.

Nor does the statute by itself provide guidelines for identifying the particular governmental interests that might outweigh a federal employee's first amendment interests in a Pickering-type balancing. Sections 7501 and 7512 provide the general standard for sanctionable misconduct of all sorts; the task of providing more particularized standards for specific conduct, including employee disclosures, is left to the Civil Service Commission and the employer agencies themselves. ${ }^{110}$ These agencies, of course, cannot perform the function of the courts by pre-balancing the interests involved in making or preventing certain disclosures and declaring some to be outside the scope of an employee's constitutional rights. But agency regulations can serve the important function of identifying specific governmental interests that might justify restrictions on employee disclosures in particular areas. Such regulations can provide some advance notice to employees as to the consequences of disclosure deemed most harmful by their employers, and can promote efficient operation of the agencies by allowing them to prevent the most harmful disclosures by clear rules rather than to assert their interests only in justifying sanctions imposed for unprotected disclosures after the harm has occurred.

The adequacy of current regulations in performing this function of setting comprehensive and detailed standards is questionable. The Civil Service Commission regulations that might be applicable in the case of an employee disclosure do not focus specifically on the disclosure problem. They first repeat the general standard of section 7501(a), 11 including among the possible sufficient "causes" for dis-

unnecessarily vague and overbroad and that it would chill the exercise of an employee's speech rights. Arnett v. Kennedy, 416 U.S. 134, 227-31 (1974) (Marshall, J., dissenting).

109 Of course, the statute could be challenged as unconstitutionally applied in a particular instance of sanction for an employee's disclosure under Pickering.

${ }^{110}$ Cf. Leonard v. Douglas, 321 F.2d 749, 752 (D.C. Cir. 1963).

I11 5 C.F.R. \& 752.104(a) (1975). 
missal a "reasonable doubt" as to the employee's loyalty to the government. ${ }^{112}$ In a separate part of the regulations, certain minimum standards of conduct for government employees, which are to be implemented by regulations of each agency, are set out. ${ }^{113}$ Among the actions proscribed in this part by regulation 735.201(a) are any that might result in, or create the appearance of:

(a) Using public office for private gain; . . . (c) Impeding Govermment efficiency or economy; . . . (e) Making a Government decision outside official channels; or (f) Affecting adversely the confidence of the public in the integrity of the Government. ${ }^{114}$

Each of these rules might be applicable, under various circumstances, to an employee who has made a public disclosure of wrongdoing by his agency employer. But they are still only general standards for all civil service employees, not directed specifically at the problem of disclosures, and they do little to advance the particularized identification of government interests in restricting employee disclosures.

Although it might be impossible to define in advance all situations in which such governmental interests might be injured, further refinement is both feasible and necessary. ${ }^{115}$ The Administrative Conference has suggested that the Civil Service Commission's Board of Appeals and Review, which hears appeals from adverse actions imposed under section $7512(\mathrm{a}),{ }^{116}$ make its decisions available to other agencies and employees and to the public. ${ }^{17}$ This opening of the Commission's currently secret body of precedents would provide the federal employee with more explicit notice of the types of behavior, including disclosures, previously upheld as grounds for dismissal.

A potentially more comprehensive method of identifying restriction-justifying governmental interests is for each of the

112 Id.; see id. $\S 731.201$ (f). The regulations also specifically exclude "partisan political reasons" as sufficient cause for dismissal. Id. $\$ 752.104$ (b).

"S See id. $\$ 735.101$, (stating the purpose of the standards as assuring "the proper performance of the Government business and the maintenance of confidence by citizens in their Government" by avoiding "misconduct and conflicts of interest").

I"I Id. \$ 735.201a. See also id. \$735.209 (prohibiting "dishonest . . or notoriously disgraceful . . . conduct, or other conduct prejudicial to the Government"); id. $\$ 735.206$ (prohibiting use of inside information to further a private interest).

115 See 2 Admin. Conf. Recomm. \& Rep. 1054 (1972). Justice Marshall disagreed with the implication of the plurality opinions in Arnett $v$. Kennedy that further refinement is impossible. See Armett v. Kennedy, 416 U.S. 134, 230 n.32 (1974) (Marshall, J., dissenting).

I1" 5 U.S.C. $\$ 7701$ (1970).

117 The Board has done so in more than 600 cases of various types of misconduct. 2 ADMIN. Conf. Recomm. \& ReP. 1054 (1972). 
agency employers to promulgate its own narrower regulations. Ideally, such regulations would take the form of categorizations of occupational duties and corresponding qualities of those duties relevant to assessing the impact of certain disclosures. Each agency, by virtue of its relatively finite number of job classifications and occupational duties, would be better able than a court faced with isolated employee disclosures or the Civil Service Commission faced with a much wider array of job situations to begin to give some definition to the limits of permissible employee disclosure. Drawing up a truly comprehensive set of explicit standards is probably not feasible, given the complex matrix formed by variable job situations on the one hand and types of disclosures on the other. But there is certainly some potential in this approach for putting the government employee who contemplates disclosing agency wrongdoing on more solid ground.

The response of the federal agencies to this need for refining the general standards for employee conduct is varied. Some agencies go no further than to reproduce almost verbatim the general Civil Service Commission regulations. ${ }^{118}$ Others have promulgated regulations dealing specifically with narrow areas of employee disclosure in which special problems may arise. ${ }^{119}$ But the problems of disclosure of agency wrongdoing and of critical public comments by agency employees are largely left to general standards like those of Civil Service Commission regulation 735.201(a). ${ }^{120}$ Some agencies bolster the "adversely affecting public confidence" standard by asserting that agency interests in maintaining such confidence are especially high..$^{121}$

Two provisions that appear in most regulations are important for assessing the sufficiency of each agency's resolution of the disclosure problem. The first, promulgated by each agency under the express direction of Civil Service Commission regulation $735.105(\mathrm{~b}),{ }^{122}$ provides that certain agency personnel are available to give "authoritative advice and guidance" as to the interpretation of

118 The FTC's regulations, for example, merely incorporate the Civil Service Commission's basic regulations. See, e.g., 16 C.F.R. $\$ \S 0.735-10,0.735-15,0.735-18$ (1975) (reproducing the language of $5 \mathrm{id}$. $\$ 735.201 \mathrm{a}, 735.206,735.209$ (1975), respectively).

${ }^{119}$ See, e.g., 28 id. $\$ 50.2$ (1974) (Justice Department regulation setting out policy on release of information relating to criminal and civil proceedings).

${ }^{120}$ See, e.g., 10 id. § 0.735-49a (1975) (AEC); 16 id. § 0.735-10 (1975) (FTC); 24 id. § 0.735-202 (1974) (HUD); 28 id. $\S 45.735-2$ (c) (1974) (Department of Justice); 45 id. $\S 73.735$ 305 (1974) (HEW).

${ }^{12 t}$ See, e.g., 10 id. $\S 0.735-1$ (1975) (AEC); 24 id. § 0.735-201(b)(i) (1974) (HUD).

${ }^{122} 5$ id. $\S 735.105$ (b) (1975). 
any of the employee conduct regulations. ${ }^{123}$ This makes it possible for the agency to give some advance warning to employees that agency interests asserted generally under the regulations would be harmed in the specific circumstances of a particular disclosure. The system may deter some employees from seeking an advisory interpretation if it requires them, for example, to disclose the wrongdoing of a superior in order for the counselor to determine whether further disclosure may be cause for the employee's own dismissal or other sanction. But this takes on elements of a petition, and the agency may have an interest in channeling contemplated disclosures through an agency superior rather than making rules comprehensive enough for an employee to judge the effects of a disclosure himself.

The second important provision of many agencies' regulations is their express incorporation of the Code of Ethics for Government Service adopted by the Eighty-Fifth Congress. ${ }^{124}$ One of the tenets of that Code is that government employees should "[e]xpose corruption wherever discovered." 125 By incorporating this provision among its own standards for employee conduct, a federal agency explicitly recognizes the public interest in encouraging its employees to make disclosures of agency wrongdoing. The employee is thus given notice that there is a strong interest, and one weighted with the interest of the public, to be balanced against this agency's selfidentified interests in nondisclosure.

State government employees are given substantive protection against unjustified sanction for disclosures of employer wrongdoing under a variety of statutory schemes. Most states either prescribe a general standard of "cause" or "just cause"126 or specify reasons, in the language of the statute or in state civil service commission regulations, that may constitute adequate cause for removal of a state employee. ${ }^{127}$ Thus, the same potential for clarifying the balancing of

${ }^{123}$ See, e.g., 10 id. $\$ \S 0.735-3(\mathrm{~b})$-(h) (1975) (AEC); 16 id. § 0.735 .5 (1975) (FTC); 24 id. $\S 0.735-104$ (b) (1974) (HUD); 28 id. $\S 45.735-26$ (b) (1974) (Department of Justice); 45 id. $\S$ 73.735-104 (1974) (HEW).

121 H.R. Con. Res. 175, 85th Cong., 2d Sess., 104 Cong. REc. 13556-57 (1958) (reprinted at 72 Stat. B12 (1958)). "The resolution creates no new law." 104 CoNG. REc. 13556 (1958) (remarks of Senator Johnson). See, e.g., 10 C.F.R. $\S$ 0.735-3(a) (1975) (AEC); 28 id. $\$ 45.735$ 2(d) (1974) (Department of Justice); cf. 24 id. $\S 0.735-201$ (b)(3) (1974) (HUD).

${ }^{125}$ H.R. Con. Res. 175, 85th Cong., 2d Sess. § 9, 104 CoNG. REc. 13556 (19E8) (reprinted at 72 Stat. B12 (1958)).

12\% See, e.g., Cal. Gov't Code $\S 19500$ (West 1963) ("cause"); Conn. Gen. Stat. AnN. $§$ 5-240(c) (1957) ("good of the service"); Ill. Rev. Stat. ANN. ch. 24, $\$ 10-1-18$ (Smith-Hurd Supp. 1974) ("cause"); Mass. ANn. Laws ch. 31, \$ 43(a) (1973) ("just cause”); PA. Stat. AnN. $\S 741.807$ (Supp. 1974) (“just cause”); cf. Mich. Const. art. 11, \& 5 (West 1967) (conferring right of appeal on "aggrieved" employees).

${ }^{127}$ See, e.g., AlasKa Stats. $\$ 14.20 .170$ (1971) (specifies and defines incompetency, im- 
interests required by Pickering exists for state law as for federal law, and the responses are likewise varied. ${ }^{128}$

Generally, then, the substantive rights of government employees to disclose agency wrongdoing are not expanded by state and federal statutes. Some of the agency regulations promulgated under statutes prohibiting adverse employment actions other than for cause may serve to give an employee contemplating disclosure some advance notice of the agency's self-perceived interests in nondisclosure. The balancing of the employee's interests against those of his employer, however, must be undertaken during administrative proceedings through which the employer imposes sanctions for the disclosure or during judicial proceedings through which the employee challenges those sanctions.

\section{Procedural Rights of the Public Employee.}

The efficacy of various substantive protections for disclosing employees depends in the first instance on the procedures through which they may be vindicated. Many of the notable advances in public employee rights have occurred in this area, and procedural protections remain a central issue in efforts to expand them even further. The factors that make the procedural aspect a focal point of employee rights are largely pragmatic. From the viewpoint of the courts, the procedures by which the government seeks to restrain speech are clearer objects of judicial scrutiny than the form of speech restrained, and the validity of a particular restraint might turn on the safeguards afforded in imposing it. ${ }^{129}$ Legislatures may attempt to avoid some of the complexities of describing substantive guidelines in detail by providing extensive administrative and judicial procedures by which general substantive standards are to be

morality, and substantial noncompliance with rules, regulations, laws and by-laws as exclusive grounds); N.Y. CIv. SERv. LAW \$75 (McKinney 1973) (incompetency and misconduct as exclusive grounds). The New Jersey statute, N.J. STAT. ANN. \$ 71:111.15-2 (1960), provides that the state's civil service commission shall enumerate the reasons "which shall be considered just cause." Despite the mandate for a closed list, the commission has left its category of causes open-ended by prescribing that "removals may be made for sufficient causes other than those listed . . ." N.J. ADMIN. CodE §4:1-16.9(a) (Supp. 1973). See also OHro REv. Code ANN. \& 1124.34 (Supp. 1974) (includes nine specific grounds for removal and "any other failure of good behavior, or any other acts of misfeasance (or) malfeasance . . .").

${ }^{123}$ Alaska is one state that specifically addresses the problem of employee disclosure, but it only codifies the holding in Pickering. ALASKa STATS. $1 \$ 14.20 .095$ (1971). Most other states handle the problem under a general standard such as insubordination or misconduct. See statutes cited at note 127 supra.

129 See Speiser v. Randall, 357 U.S. 513, 521 (1958). Compare Kuntz v. New York, 340 U.S. 290 (1951), with Feiner v. New York, 340 U.S. 315 (1951). 
implemented. Finally, the nature and timing of the procedure by which a government employee is entitled to challenge his dismissal or other sanction may affect his chances of succeeding and his ability to undertake the challenge in light of the costs involved in doing so. ${ }^{130}$ Thus, a description of the procedures that the government must follow in imposing employment sanctions is an important part of a survey of the protections provided for government employee disclosures.

\section{A. Constitutional Protections.}

The constitutional guarantee of procedural due process may only be invoked by persons who are deprived of "life, liberty, or property" by actions of the state or federal government. ${ }^{131}$ Thus, before the due process clause is applicable at all, a government employee must show that the sanctions imposed on him for his disclosure actually entailed a deprivation of his liberty or of a property interest.

The Supreme Court's opinions in the companion cases of Board of Regents $v$. Roth ${ }^{132}$ and Perry $v$. Sindermann ${ }^{133}$ provide the basis for definitions of liberty and property to be applied in considering a due process claim. Both cases involved state college teachers whose contracts had not been renewed at their expiration dates, allegedly because of the teachers' public criticisms of their employers' policies. ${ }^{134}$ Roth had been employed for fewer than the four years required to gain tenure. The Court reversed the lower court's ruling that the college was bound by the Constitution to provide him with a hearing and reasons as to its failure to rehire him. It held that Roth had not shown a deprivation of his liberty, which might have consisted either of injury to his reputation in the community because of the nature of the reasons the college asserted for his not being rehired or of foreclosure of future employment opportunities because of the fact that he was not rehired. ${ }^{135}$ Nor did he establish the deprivation of a cognizable property interest, which the Court held could only be based upon an entitlement to reemployment that was supported by "existing rules or understandings that stem from an inde-

\footnotetext{
${ }^{130}$ Cf. Board of Regents v. Roth, 408 U.S. 564, 585 (1972) (Douglas, J., dissenting).

131 U.S. ConsT. amend. V; id. amend. XIV, $\$ 1$.

132408 U.S. 564 (1972).

133408 U.S. 593 (1972).

13 Board of Regents v. Roth, 408 U.S. 564, 568 (1972); Perry v. Sindermann, 408 U.S.

125 Board of Regents v. Roth, 408 U.S. 564, 573 (1972).
} 593, 595 (1972). 
pendent source." ${ }^{136}$ Having thus disposed of Roth's procedural due process claim, the Court remanded his case for trial on the issue of whether the college's failure to rehire him had violated his first amendment rights. ${ }^{137}$

Sindermann, on the other hand, had been employed under four successive one-year contracts at a state college that lacked a formal tenure system. The Supreme Court held that Sindermann's due process claim had improperly been dismissed before trial, since he might have established a legitimate claim of entitlement to reemployment by proving his allegations of an informal tenure system based on the policies and practices of the college. ${ }^{138}$ The Court emphasized as well that Sindermann's first amendment claim was wholly independent of his due process claim, and that the existence of a property interest was irrelevant to the sufficiency of a claim brought under Pickering. ${ }^{139}$

The due process clause may also be applicable under Roth and Sindermann to government-imposed sanctions other than outright dismissal or refusal to rehire. In Bottcher v. Florida Department of Agriculture and Consumer Services, ${ }^{140}$ for example, a chemist was given a conditional rating (indicating poor or substandard performance) by her superiors, allegedly in retaliation for disclosures she had made concerning inadequate testing methods used by her employer agency. ${ }^{141}$ Since the rating constituted an impediment to Bottcher's professional reputation and future advancement, the district court said, it could not be imposed without the procedural protections guaranteed by the due process clause..$^{142}$

Beyond the question of whether the due process clause is applicable in the case of a particular sanction is the difficult question of what specific procedures are mandated when the clause does apply. That question must be resolved by balancing the government's interest in expeditious sanction of the disclosing employee against the interest of the employee in avoiding the summary imposition of such a sanction. ${ }^{143}$

${ }^{136}$ Id. at 577.

15 See id. at 568 \& n.5, 574-75 \& n.14, 579.

138 Perry v. Sindermann, 408 U.S. 593, 601-03 (1972).

${ }^{139}$ Id. at 596-98. Despite the fact that a nontenured employee might have no entitlement to reemployment, allowing the government to deny the benefit of reemployment because of the employee's exercise of first amendment rights would be to allow the government to restrict indirectly what it is forbidden from restricting directly by positive sanctions. See id. at 597.

${ }^{110} 361$ F. Supp. 1123 (N.D. Fla. 1973).

111 Id. at 1128 .

142 Id. at 1128-29.

"ws See Goldberg v. Kelly, 397 U.S. 254, 263 (1970); Cafeteria \& Restaurant Workers, 
Several significant features of government employees' procedural due process rights have been considered by the courts, and the few that are most relevant to an employee's dismissal for disclosing agency wrongdoing are worth noting. In Fitzgerald $v$. Hampton ${ }^{144}$ the District of Columbia Circuit held that a former federal employee's termination hearing was required to be open to the press and public, in accordance with his request. ${ }^{145}$ The court first held that the plaintiff's statutory employment rights were within the liberty and property concept of the fifth amendment, ${ }^{148}$ and then interpreted the due process guarantee as requiring that the hearing be open. ${ }^{147}$ Exposure was of great consequence in this case because of the public interest in the circumstances surrounding the abolition of Fitzgerald's position after his testimony to the Senate-House Joint Economic Committee exposed the cost overruns of the Air Force C-5A program. . $^{148}$

The timing of evidentiary hearings has perhaps an even more significant effect than openness on the willingness of an employee to make a protected disclosure. Where the employee faces the probability of months of being off the payroll even if he is ultimately successful in challenging a dismissal action, he will be deterred from exercising his statutory and constitutional rights of expression to their fullest extent. ${ }^{199}$ The timing of the required hearing was one of the major due process issues that split the Supreme Court in Arnett $v$. Kennedy ${ }^{150}$ The three-member plurality in Arnett, considering a due process challenge to the statutory procedures provided for adverse actions imposed by federal agencies under section 7501(a), ${ }^{151}$ held that the property interest in continued employment created by

Local 473 v. McElroy, 367 U.S. 886, 895 (1961).

iw 467 F.2d 755 (D.C. Cir. 1972).

145 Id. at 766. The Commission's present position is that the examiner may still deny the employee's request for a public hearing on his appeal if the agency objects and if, in his determination, a closed hearing is "in the best public interest." 5 C.F.R. $\$ 772.307$ (c)(5) (1975).

ws 467 F.2d at 762 .

147 The court noted that the administrative hearing was of a quasi-judicial character, and that due process in such hearings does not yield to administrative convenience or expediency. Id. at 766-67; see Ohio Bell Tel. Co. v. Public Util. Comm'n, 301 U.S. 292, 304-05 (1937).

"1* A fully descriptive commentary on this case is found in WHISTLE BLOWING note 1 supra at 39-54.

11' More than 75 percent of adverse actions contested within employer agencies require longer to decide than the 60 days prescribed by Commission regulations, and 5 percent are in process for longer than a year. In most agencies, the employee is off the payroll throughout the appeals process. 2 Admin. Conf. Recomm. \& Rep. 1016 (1972).

150416 U.S. 134 (1974); see text and notes at notes 76-78 supra.

151 See text and notes at notes 104-07 supra. 
the statute was conditioned by the procedural limitations set out in the same section; since Kennedy had been discharged under those procedures, he had not been deprived of a property interest and therefore had no due process claim. ${ }^{152}$

The six other members of the Court rejected this analysis, but differed as to what timing the due process clause required once it was held to be applicable. Justices Powell and Blackmun, viewing the hardships sustained by a discharged employee in awaiting the hearing that he would receive in appealing his dismissal as uncompelling, ${ }^{153}$ would have held that due process does not require an evidentiary hearing prior to dismissal, and thus voted to uphold the statute. ${ }^{154}$ Justice White felt, after balancing the agency's and employee's interests, that a prior hearing was required, but that the statutory provision for pretermination notice and for the employee to respond in writing satisfied that constitutional requirement. ${ }^{155}$ Justice Marshall, writing for the dissenters, ${ }^{156}$ evaluated the interests differently from Justices Powell and White and concluded that the failure of the statute to provide a pretermination evidentiary hearing violated the employee's due process rights. ${ }^{157}$ The hardship imposed on the discharged employee by the delay that occurred before he would receive a hearing on appeal, according to Justice Marshall, was potentially devastating. ${ }^{158} \mathrm{He}$ found the government's asserted interests in expeditious dismissal of troublesome employees, on the other hand, to be contrary to its actual experience..$^{159}$

A final element of a government employee's procedural due process rights that seems quite significant in the context of employee disclosures was also raised in Justice White's opinion in Arnett. Although he thought that the statutory procedures satisfied due process requirements as far as they went, he would have affirmed the lower court's invalidation of the particular dismissal on

${ }^{152}$ Arnett v. Kennedy, 416 U.S. 134, 151-52, 155 (1974) (opinion of Rehnquist, J., joined by Burger, C.J., and Stewart, J.). The plurality also found that there was no denial of liberty in violation of Kennedy's due process rights, since a hearing afforded by administrative appeal provided him with an opportunity to clear his name and reputation. Id. at 157.

${ }^{153}$ Id. at 169 (Powell, J., concurring in part); cf. Sampson v. Murray, 415 U.S. 61, 83-84, 90-91 (1974).

150416 U.S. at 171.

135 Id. at 195-96.

${ }^{156}$ Justice Douglas joined Justice Marshall's opinion, but also filed a separate dissent in which he argued that any dismissal based on an employee's critical speech violated his first amendment rights and that no governmental interests should be permitted to outweigh those rights. Id. at 203-06 (Douglas J., dissenting).

${ }^{157} I d$. at 226-27 (Marshall, J. dissenting).

iss Id. at $220-22$.

${ }^{159}$ Id. at 224-26. 
the ground that Kennedy was not provided an impartial hearing officer. ${ }^{160}$ Since the agency officer who made the dismissal determination was the very superior whom Kennedy had accused of attempted bribery, "the risk and the appearance" of bias were so great that Justice White would have found a denial of due process. ${ }^{161} \mathrm{~A}$ similar problem would arise to some degree in every disclosure of agency wrongdoing. When the employee's dismissal is predicated on personally slanderous disclosures against the agency official who will decide whether the dismissal is justified under the applicable statutes, Justice White's position seems quite correct. Even when the employee's disclosure alleges improper actions of persons other than the hearing officer himself, a similar question of partiality might arise; any agency hearing on the issue of whether public criticism of the agency should justify sanctions against the critical employee might be seen as likely to give undue weight to the agency's own interests. ${ }^{12}$ But labelling such general prejudice a due process violation is probably appropriate only where the hearing officer is personally involved, as he was in Arnett. In any other case, the agency's assertion of its own interests over the employee's in the administrative hearing is permissible as long as the employee can vindicate his first amendment rights by bringing a suit for reinstatement or other remedy. The court will undertake the ultimate balancing of agency interests against employee's first amendment rights. ${ }^{163}$

\section{B. Statutory Protections}

The basic procedural protections afforded tenured federal employees by statute are provided in the Lloyd-LaFollette Act and are expanded in some cases by regulations promulgated by the agencies themselves. When an agency proposes to sanction an employee under section 7502 (a) or $7512(\mathrm{a}){ }^{164}$ the employee must be provided with notice of the action, a specification of reasons or charges, an opportunity to answer the notice in writing (and in person if the adverse action is against a "preference eligible" employee), and notice of the agency's final determination. ${ }^{165}$ The Supreme Court upheld this procedure against a due process claim in Arnett, with

\footnotetext{
160 Id. at 202 (White, J., dissenting in part).

${ }^{161}$ Id. at 196-99.

${ }_{162}$ Cf. Ring v. Schlesinger, 502 F.2d 479, 490 (D.C. Cir. 1974).

103 Id.

Iot See text and notes at notes 104-07 supra.

its 5 U.S.C. $\$ \S 7501$ (b), 7512(b) (1970).
} 
two Justices relying on the provision of a full evidentiary hearing on administrative appeal ${ }^{166}$ to find it constitutional. ${ }^{167}$ But despite the fact that the Court held the statutory procedure constitutionally sufficient, some agencies have expanded the procedural rights of their employees by regulation. At least nine agencies, for example, provide for a full evidentiary hearing prior to an employee's dismissal. ${ }^{168}$ The Administrative Conference has recommended that such pretermination hearings be required universally, but that the agency be permitted to reassign the employee or place him on administrative leave with pay when it determines that his continued employment pending the hearing would adversely affect department operations or morale. ${ }^{169}$ This proposal thus gives full credence to the interests of the government in expeditious removal of disruptive employees and to the interests of employees in being able to have their defenses to a dismissal considered in a full hearing without sacrificing their livelihood pending an appeal. Since both sides are accommodated, the due process balancing on which the Court split on Arnett would be avoided.

Another aspect of a federal employee's procedural protections that the Supreme Court has recently considered is the availability of injunctive relief against improper agency action. In Sampson $v$. Murray, ${ }^{170}$ the Court held that an injunction was properly denied a probationary employee who sought to enjoin her discharge on the ground that it was accomplished in violation of the Civil Service Commission's procedural regulations. ${ }^{171}$ The Court's justification for

${ }^{186} 5$ U.S.C. $\$ 7701$ (1970); 5 C.F.R. $\$ 772.307$ (1975).

${ }^{167}$ See text at notes 153-54 supra.

${ }^{163}$ Those nine agencies, which include the Departments of Health, Education and Welfare, Housing and Urban Development, Justice, and the Civil Service Commission itself, account for no more than ten percent of the total cases of employees contesting adverse actions taken against them. 2 ADMIN. CoNF. RECOMM. \& REP. 1016 n.38 (1972).

168 Admin. Conf. of the United States, 1972-73 REPORT, Recommendation 72-8 (1973). Presently, agencies may place an employee in a nonduty status with pay only insofar as is necessary to effect his suspension during the pretermination notice period, and for a maximum of five days. 5 C.F.R. $\$ 752.202$ (c)(3) (1975).

The committee also proposes that employees subject to adverse action have the right to elect a hearing that is open to the public, except where an employing agency can establish good cause for keeping the hearing closed.

The public has an interest in monitoring the administration of justice at all levels of government . . . Except in rare cases involving national security . . . [employing agencies and the Civil Service Commission] have no legitimate interest in preserving the secrecy of their hearing process or the facts they produce.

1 Admin. Conf. Recomm. \& Rep. 1061-62 (1972).

170415 U.S. 61 (1974).

17 Murray, a provisional GSA employee, claimed that her discharge was based at least in part on conduct prior to her federal employment, and that she was denied an opportunity 
its holding was that any loss occasioned by the plaintiff's being off the payroll while awaiting an appeal could be remedied under the Back Pay Act, which permits recovery of pay lost because of "unjustified or unwarranted personnel action"172 and that plaintiff Murray had, therefore, shown no irreparable injury. ${ }^{173}$

Almost all state statutes that protect public employees from sanction other than for cause also provide procedural protection of the substantive right for state employees; requirements of notice of a proposed adverse action and the right to a hearing are the most common features. Although ambiguous terms are often used to describe the causes that may justify sanction, several states have had the foresight to require that the notice of sanction describe the reasons for the action with specificity. ${ }^{174}$ Consequently, the employee who wishes to prove that the motivation for the state's action against him is unlawful is in a better position to do so when the notice is of the form required by these statutes.

Several state legislatures have also considered the nature of the hearing to be provided, and have granted important concessions to the employee. Statutes in at least four states require that the hearing be held before the effective date of the termination, ${ }^{175}$ and as many allow for opening the hearing to the public. ${ }^{176}$ Two states, perhaps out of cognizance of the public interests in diminishing abuse of the power of removal, provide that the state civil service commission may investigate a removal upon its own initiative. ${ }^{177}$

to file an answer to the notice of proposed adverse action, as provided by 5 C.F.R. $\$ 315.805(a)$ (1975). 415 U.S. at 64-65.

1725 U.S.C. $\$ 5596$ (1970).

133 415 U.S. at $90-91$.

17 See, e.g., Alaska Stat. $\$ 14.20 .180$ (a)(1971)(a statement of cause and a complete bill of particulars); CoNn. GEN. STAT. ANN. 1 \$ 5-240(c) (1969) (the reasons for dismissal set forth in sufficient detail to indicate cause); Ilt. ANN. STAT. ch. 24 \$10-1-18 (Smith-Hurd Supp. 1975) (the specific improper or illegal act alleged to have been committed); MAss. ANN. LAws ch. 31 \$43(a)(1973)(reasons specifically given); N.J. STAT. ANN. 11:15-3 (1960)(removing party completes form listing cause constituting grounds for removal and act consituting such cause and delivers same to employee). Others are not as demanding. See, e.g., OHIO REv. CODE ANN. \$124.34 (Supp. 1973)(copy of order of sanction, stating reasons therefore); PA. Stat. ANN. tit. $71 \S 741.950$ (Supp. 1975) (reasons for the action).

175 Alaska Stat. \$ 14.20.180(c) (1971); Ill. AnN. Stat. ch. 24 \& 10-1-18 (Smith-Hurd Supp. 1974); Mass. Ann. Laws ch. $31 \S 43$ (a) (1973); New YorK Crv. Serv. Laws $\$ 75$ (McKinney 1973). Pennsylvania ameliorates the lack of a right to pretermination hearing by specifying a right to back pay. PA. Stat. AnN. tit. $71 \S 741.951$ (Supp. 1975).

17" Alaska STAT. $\$ 14.20 .180$ (b)(1) (1971) (public hearing upon employee's request); MASS. ANN. Laws ch. $31 \S 43$ (b) (1973) (public hearing upon request of either party); N.J. Stat. ANN. 11:15-5 (1960)(investigation, inquiry or hearing shall be open to public); PA. STAT. ANN. tit. $71 \S 741.951$ (Supp. 1975) (public hearing).

17 N.J. Stat. Ann. 11:15-4(1960); PA. Stat. AnN. tit. $71 \S 741.951$ (Supp. 1975). 
Massachusetts law even provides a schedule of reimbursements whereby employees may recover virtually all legal expenses in defending against an unwarranted state employment action. ${ }^{178}$

The degree of procedural protections conferred by state statutes often exceeds that provided by the Lloyd-LaFollette Act, but the gap may be narrowed to the extent that agency regulations and judicial decisions have broadened the rights which appear in the federal Act itself. The state pattern of explicitly describing the safeguards of the dismissal procedure in dismissal statutes has the advantages of uniformity and accessibility. Thus, state legislation in this area both expands the protections afforded government employees and may improve the awareness of employees as to how and when they may be invoked.

\section{Conclusion}

Public employees who disclose the improper actions or policies of their agency employers may rightfully claim a strong public interest in support of their exercise of constitutional and statutory rights to speak out without retribution. The benefit to the public of their use of their special expertise and access in blowing the whistle on governmental misfeasance is potentially great. But there is a different public interest-that of efficient operation of government agencies-on the other side. Agency employers could be unduly impeded in performing their necessary function if an unqualified right of immunized disclosure were established.

This comment has attempted to indicate the scope of the disclosing employee's protection by surveying the constitutional and statutory provisions that are relevant to accommodating the conflicting interests. The employee's first amendment right to freedom of speech under Pickering is only to be balanced against the interests the government asserts, with the balance to be struck by the courts in each case. The first amendment guarantee of a right of petition, the first amendment-based prohibition against vague and overbroad rules, and the statutory right of federal employees to petition Congress all may describe objectively broader protection for the employee in certain circumstances where the counter-balancing interests are more predictable. Finally, although statutes and regulations that prescribe general substantive and procedural standards for employment sanctions and the constitutional guarantee of cer-

${ }^{178}$ Mass. Ann. Laws ch. $31, \S 43(\mathrm{~h})$ (1973). Unlike some states, the Massachusetts act is applicable even where the employee's office or position is abolished. Id. $\S 43(a)$. 
tain procedural protections cannot preempt the ultimate resolution of conflicting interests, they do serve to clarify and make more fair the initial assertion of the government's interests in restricting an employee's disclosures.

Mitchell J. Lindauer 